\title{
PENGARUH CASH FLOW, PROFITABILITAS, DAN UKURAN PERUSAHAAN TERHADAP KEBIJAKAN DIVIDEN (Studi Empiris Pada Perusahaan Manufaktur Yang Terdaftar Di Bursa Efek Indonesia Tahun 2018- 2020)
}

\author{
Eko Prasetyo \\ Muhammad Reza Soekamto Putra \\ Program Studi Akuntansi - Universitas Kahuripan Kediri \\ E-mail: ekoprasetyo@ Kahuripan.ac.id
}

\begin{abstract}
Abstrak
Penelitian ini bertujuan untuk mengetahui dan menganalisis bagaimana pengaruh cash flow, profitabilitas dan ukuran perusahaan terhadap kebijakan dividen. Pada perusahaan manufaktur yang terdaftar di Bursa Efek Indonesia periode 20182020. Perusahaan manufaktur yang terdaftar di Bursa Efek Indonesia tahun 2018 - 2020 menjadi populasi dalam penelitian. Teknik pengambilan sampel yang digunakan adalah purposive sampel yang kemudian didapatkan 48 sampel. Teknik analisis data dalam penelitian ini adalah analisis regresi linier berganda. Hasil penelitian menunjukkan bahwa variabel cash flow, profitabilitas, dan ukuran perusahaan berpengaruh signifikan terhadap kebijakan dividen, sedangkan variabel likuiditas tidak berpengaruh signifikan terhadap perubahan Laba. Berdasarkan hasil uji $\mathrm{F}$ diketahui bahwa semua variabel bebas secara simultan berpengaruh signifikan terhadap kebijakan dividen.
\end{abstract}

Kata kunci : cash flow, profitabilitas, ukuran perusahaan, kebijakan dividen

\begin{abstract}
This study aims to determine and analyze how the effect of cash flow, profitability and firm size on dividend policy. For consumer goods companies listed on the Indonesia Stock Exchange for the 2018-2020 period. The technique used in this study obtained data results. Manufacturing companies listed on the Indonesia Stock Exchange in 2018 - 2020 are the population in the study. The sampling technique used was purposive sampling which then obtained 48 samples. The data analysis technique in this research is multiple linear regression analysis. The results showed that the cash flow, profitability, and firm size variables had a significant effect on dividend policy, while the liquidity variable had no significant
\end{abstract}


effect on changes in earnings. Based on the results of the F test, it is known that all independent variables simultaneously have a significant effect on dividend policy.

Kata kunci : cash flow, profitability, company size, dividend policy.

\section{PENDAHULUAN}

Pengembalian ataupun profit dari pemodalan seorang investor bisa berbentuk capital gain ataupun dividen. Dividen adalah profit bersih yang diserahkan industri pada pemegang saham, sebaliknya capital gain adalah beda antara harga beli dengan harga pasar (Windyasari dan Widyawati, 2017). Pada teori kebihkan dividen bird in the hand theory melaporkan jika penanam modal memilah pembayaran dividen era depan dari capital gain, karena memperhitungkan capital gain dikira beresiko besar (Vidia \& Darmayanti, 2016).

Kebijakan dividen adalah salah satu kapasitas moneter dan merupakan bagian penting dari pilihan subsidi organisasi (Van Home \& Wachowicz, 2007). Brigham \& Houston (2010) menyatakan bahwa strategi laba yang ditetapkan oleh organisasi dapat memutuskan berapa banyak pembagian manfaat yang harus dibayarkan kepada investor dan ukuran asset yang akan diinvestasikan kembali dalam organisasi

Kebijakan dividen dilaksanakan oleh para manajemen guna membagikan laba diperoleh untuk pada pemangku kepentingan (investor). Keputusan dalam kebijakan dividen dapat memberikan efek yang berlawanan bagi perusahaan, ketika kebijakan dividen tersebut dapat meningkatkan rasio pembayaran bagi perusahaan, ketika rasio pembayaran meningkat maka akan berdampak terhadap perusahaan yaitu kurangnya ketersediaan arus kas bagi perusahaan. Berdasarkan teori Signalling Hypothesis menurut Modligani dan Miller, menyatakan bahwa kenaikan dividen adalah ciri untuk penanam modal jika manajemen akan memperhitungkan pemasukan yang baik di masa depan. Sebaliknya, penyusutan dividen ataupun kenaikan di bawah tingkatan normal dikira investor selaku pertanda masa susah bagi industry, yang berakibat pada penyusutan harga saham pasar (Gautama \& Haryati, 2014).

Kebijakan dividen sangat penting untuk ditetapkan dengan tepat karena menyangkut pemegang saham yang merupakan salah satu sumber modal utama dari perusahaan tersebut. Peranan dividen begitu penting, oleh karena itu perusahaan tidak mengumumkan dividen yang lebih rendah dari tahun sebelumnya. Perusahaan yang mengumumkan pembagian dividen yang lebih rendah dari tahun sebelumnya akan memberkan sinyal yang buruk bagi investor yang akan mempertimbangkan kembali untuk berinvestasi ke perusahaan tersebut.

Pada penentuan kebijakan dividen yang tepat tidaklah mudah, manajer harus melihat berbagai aspek khusus tingkat kas yang dimiliki perusahaan. Namun, tingkat kas yang dimiliki perusahaan juga dilihat dari berbagai aspek seperti kinerja keuangan dan ukuran perusahaan. Kinerja keuangan yang tinggi menandakan bahwa perusahaan memperoleh laba yang tinggi di periode tersebut, hal ini membuat sinyal kepada para pemegang saham bahwa perusahaan dapat menetapkan dividen dalam jumlah yang besar. 
Ukuran perusahaan merupakan gambaran yang dapat mengukur skala operasional perusahaan. Semakin tinggi ukuran suatu perusahaan maka berbanding lurus dengan biaya yang wajib dikeluarkan dalam membiayai kebutuhan, kewajiban serta aktivitas operasional yang lebih besar dari perusahaan yang skala kecil sehingga perusahaan besar diperlukan untuk menetapkan tingkat cash holding yang tinggi untuk perusahaan juga dapat membuat kebijakan dividen yang tinggi.

Menurut Kresna \& Ardini (2020), berpendapat bahwa free cash flow memiliki pengaruh positif terhadap kebijakan dividen karena kas yang dimiliki perusahaan terdapat sisa yang tersedia setelah perusahaan melakukan belanja modal dan pembayaran terhadap kewajibannya sehingga kas yang tersedia dapat digunakan membayar dividen pada periode tersebut.

Penelitian yang dilakukan oleh Masruroh et al., (2019), menyatakan bahwa pendapatan bebas secara negative mempengaruhi strategi laba yang menyiratkan bahwa kenaikan pendapatan bebas organisasi akan menyebabkan penurunan laba yang dibayarkan oleh organisasi kepada investor.

Selain free cash flow, laba dari perusahaan yang dilihat dari profitabilitas dapat mempengaruhi besar dividen. Profitabilitas merupakan elemen penting bagi sebuah perusahaan yang berorientasi pada laba menggunakan proksi Return on Assets (ROA). Sesuai dengan kewenangan organisasi, produktivitas dapat dijadikan sebagai tolok ukur untuk menentukan derajat pencapaian organisasi yang dipimpinnya, sedangkan bagi penyandang dana, manfaat dari hasil laporan keuangan dapat dijadikan sebagai salah satu tanda dalam memilih serta menempatkan sumber daya kedalam sebuah organisasi.

Berdasarkan latar belakang diatas maka tujuan dari penelitian ini adalah untuk mengetahui dan menganalisis pengaruh cash flow, profitabilitas dan ukuran perusahaan terhadap kebijakan dividen pada perusahaan manufaktur yang terdaftar di Bursa Efek Indonesia periode 2018-2020. Hasil penelitian diharapkan akan memberikan manfaat bagi berbagai pihak bagi para investor dan calon investor dalam mengambil keputusan ekonomi, dan bagi pihak manajemen perusahaan untuk membuat kebijakan perusahaan dan pengembangan ilmu bagi akademisi.

\section{TINJAUAN PUSTAKA}

\section{Dividen}

Dividen adalah pendapatan laba bersih dibayar pada pemegang saham setelah pajak dikurangi oleh laba ditahan (retained earnings). Menurut (Kresna \& Ardini, 2020) pembayaran dividen merupakan cerminan dari keadaan tingkat pembagian penentuan dividen perusahaan, ketika perusahan mempunyai laba tinggi maka memberikan tingginya penentuan pembayaran deviden yang dimungkinkan untuk dilaksanakan, apabila perusahaan mengalami penurunan dalam pembagian dividen akan memberikan sinyal yang tidak baik bagi investor.

\section{Kebijakan Dividen}

Menurut Kresna \& Ardini (2020) dalam Munfarid (2021), Kebijakan dividen merupakan keputusan apakah laba yang diperoleh perusahaan akan dibagikan kepada pemegang saham sebagai dividen atau akan ditaham dalam 
bentuk laba untuk pembiayaan investasi dimasa yang akan datang. Keputusan ini digunakan perusahaan guna menentukan kebijakan dividen berapa besar pembagian laba bersih yang akan dibagikan kepada investor sebagai dividen. Pembagian dividen ini untuk pemegang saham adalah hak mereka dalam mendapatkan keuntungan dari aktivitas penanaman saham yang dilakukan.

Tujuan dari pembagian dividen yaitu guna mensejahterakan pemegang saham, memberikan dorongan dalam menanamkan dana di pasar modal, mengevaluasi kinerja perusahaan melalui besar dividen yang dibagikan dan sebagai media komunikasi antara manajemen dengan para pemegang saham. Pembayaran dividen dianggap sebagai penyampaian informasi dalam mengetahui pertumbuhan dan prospek perusahaan (Anggraeni \& Ridwan, 2020).

\section{Arus Kas Bebas}

Menurut Subramanyam \& Wild (2017), menyatakan arus kas bebas merupakan aktivitas operasi dikurangi pengeluaran modal neto yang digunakan guna mempertahankan kapasitas produktif dan dividen saham preferen dan saham biasa dengan penilaian dalam kebijakan pembayaran. Definisi lain adalah laba operasi neto setelah pajak dikurangi kenaikan pada asset operasi neto setelah pajak dikurangi kenaikan pada asset operasi neto, kenaikan aset operasi neto, kenaikan aset operasi jangka panjang.

Free Cash Flow atau arus kas bebas merupakan aliran kas yang tersisa dari pendanaan seluruh proyek yang menghasilkan NPV (Net Present Value) prositif yang didiskontokan pada tingkat biaya modal yang relevan. Semakin besar arus kas bebas suatu perusahaan maka mempengaruhi besarnya pembayaran dividen yang harus diberikan (Pradnyavita \& Suryanawa, 2020).

\section{Profitabilitas}

Menurut Kasmir (2014), rasio profitabilitas merupakan rasio yang digunakan untuk menilai tingkat kemampuan perusahaan dalam mendapatkan keuntungan. Profitabilitas menjadi salah satu indicator yang penting bagi perusahaan karena digunakan untuk mengukur suatu kemampuan perusahaan dalam menghasilkan laba. Profitabilitas sebagai tolak ukur perusahaan untuk mengetahui efektfnya perusahaan dalam mengelola modal yang berhubungan dengan keuntungan perusahaan.

Profitabilitas adalah kemampuan suatu perusahaan dalam memanfaatkan modal perusahaan, aset perusahaan dan tingkatan penjualan agar menghasilkan laba yang nantinya menjadi dasar pembagian dividen kepada para pemegang saham.

\section{Teori Sinyal (Signalling Theory)}

Teori sinyal dikemukakan oleh Arkelof dan Spence (1973), menjelaskan bahwa suatu sinyal yang diberikan pemegang saham melalui pengumuman dividen, seandainya terjadi peningkatan dividen berarti penghasilan yang baik dimasa yang akan datang telah diramalkan oleh pihak manajerial perusahaan. Kemudian teori sinyal (signaling theory) pertama kali dikembangkan oleh Ross (1977), teori ini menjelaskan bahwa laporan keuangan yang baik merupakan sinyal atau tanda bahwa perusahaan telah beroperasi dengan baik. 
Manajer wajib memberikan sinyal mengenai kondisi perusahaan kepada pemilik sebagai wujud tanggung jawab pengelolaan perusahaan. Teori sinyal menjelaskan mengapa perusahaan mempunyai dorongan untuk memberikan informasi laporan keuangan kepada pihak eksternal. Dorongan perusahaan untuk memberikan informasi adalah karena terdapat asimetri informasi antara perusahaan dan pihak luar. Karena, perusahaan mengetahui lebih banyak mengenai informasi perusahaan dan prospek yang akan datang daripada pihak luar khususnya investor dan kreditor.

Menurut Aryani \& Fitria (2020), mengatakan bahwa teori sinyal memiliki arti sebagai alasan perusahaan memberikan informasi berupa laporan keuangan maupun non keuangan suatu perusahaan kepada pihak eksternal yaitu pemegang saham, yang berguna untuk mengurangi informasi yang diperoleh tidak akurat berhubungan dengan perusahaan kepada stakeholder sebagai pengguna informasi. Teori ini juga mendasari kebijakan dividen pada suatu perusahaan jika memberikan sinyal berupa berita baik kepada pengguna laporan keuangan perusahaan, maka para investor juga memiliki pandangan terhadap manajemen yang baik untuk perusahaan.

\section{Perumusan Hipotesis}

1. Pengaruh Free Cash Flow terhadap Kebijakan Dividen

Free Cash Flow merupakan kas di perusahaan yang seharusnya dibagikan kepada pemegang saham. Arus kas bebas yang tinggi memperlihatkan jumlah dana yang tersedia untuk aktivitas bisnis setelah penyisihan guna kebutuhan pendanaan dan investasi agar dapat dipertahankan kapasitas produksi pada tingkat saat ini (Kresna \& Ardini, 2020). Pradnyavita \& Suryana (2020), mengatakan bahwa free cash flow berpengaruh positif terhadap kebijakan dividen. Berdasarkan uraian tersebut, maka hipotesis pertama penelitian ini adalah :

$\mathrm{H}_{1}$ : Free Cash Flow berpengaruh positif terhadap kebijakan dividen.

2. Pengaruh Profitabilitas terhadap Kebijakan Dividen

Menurut penelitian Anggraeni \& Ridwan (2020) mengatakan profitabilitas berpengaruh positif signifikan terhadap kebijakan dividen. Hasil penelitian Aryani \& Fitria (2020) mengatakan sama dengan penelitian diatas, yaitu profitabilitas berpengaruh positif signifikan terhadap kebijakan dividen. Berdasarkan uraian tersebut, maka hipotesis kedua penelitian ini adalah:

$\mathrm{H}_{2}$ : Profitabilitas berpengaruh positif terhadap kebijakan dividen.

3. Pengaruh Ukuran Perusahaan terhadap Kebijakan Dividen

Menurut penelitian Mui \& Muzlina (2016), menyatakan bahwa ukuran perusahaan berpengaruh signifikan terhadap kebijakan dividen. Berdasarkan uraian tersebut, maka hipotesis ketiga penelitian ini adalah:

$\mathrm{H}_{3}$ : Ukuran perusahaan berpengaruh positif terhadap kebijakan dividen.

Berdasarkan penjabaran landasan teori, maka kerangka pemikiran yang dibangun dalam penelitian secara sistematis yakni: 


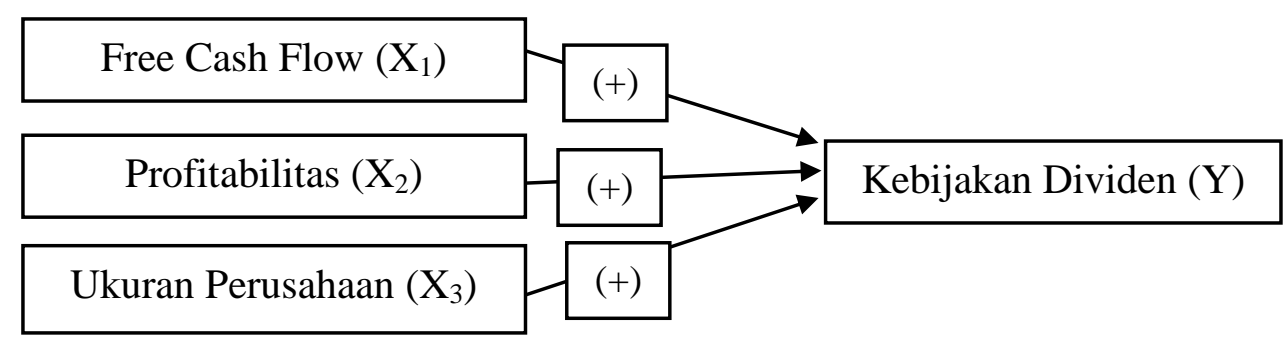

Gambar 1. Kerangka Pemikiran

\section{METODE PENELITIAN}

Teknik penelitian yang digunakan dalam penelitian ini adalah metode deskriptif, dimana metode ini merupakan suatu metode penelitian yang digunakan dalam penelitian deskriptif untuk menggambarkan fenomena yang ada. Penelitian deskriptif merupakan penelitian yang memberi uraian mengenai gejala sosial yang diteliti dengan mendeskripsikan tentang nilai variabel berdasarkan indikator yang ditelititanpa mebuat hubungan dan perbandingan dengan sejumlah variabel yang lain.

Pendekatan penelitian yang digunakan adalah pendekatan kuantitatif. Penelitian ini dilakukan dalam rangka memperoleh data sekunder dan dipergunakan sebagai pembanding dalam pembahasan nanti. Menurut (Sugiyono, 2013) (2013:148), "Populasi adalah wilayah generalisai yang terdiri atas obyek/subyek yang mempunyai kualitas dan karakteristik tertentu yang ditetapkan oleh peneliti untuk dipelajari dan kemudian ditarik kesimpulannya". Sampel Penelitian Penentuan sampel pada peneltian ini menggunakan metode purposive sampling .Pertimbangan/ kriteria yang dapat diajukan adalah sebagai berikut:

a. Perusahaan tergolong dalam kelompok perusahaan Manufaktur yang terdaftar secara berturut-turut di Bursa Efek Indonesia berdasarkan klasifikasi Indonesian Stock Exchange (IDX) selama periode penelitian yaitu tahun 2018 hingga 2020.

b. Perusahaan membuat laporan keuangan dan telah dipublikasikan secara luas serta berturut-turut pada periode tahun 2018 hingga 2020.

c. Selama periode penelitian, perusahaan membagikan dividen dan dipublikasikan berturut- turut periode tahun 2018 hingga 2020.

d. Perusahaan mengalami laba selama periode tahun 2018 hingga 2020.

e. Perusahaan yang mengalami peningkatan penjualan selama periode tahun 2018 hingga 2020.

Table 1 : Kriteria Sampel Penelitian

\begin{tabular}{|c|l|c|}
\hline NO. & \multicolumn{1}{|c|}{ Kriteria } & Jumlah \\
\hline 1. & $\begin{array}{l}\text { Perusahaan manufaktur yang terdaftar di BEI } \\
\text { berdasarkan klasifikasi Indonesian Stock Exchange } \\
\text { (IDX) periode tahun 2018 - 2020. }\end{array}$ & 152 \\
\hline 2. & $\begin{array}{l}\text { Perusahaan tidak membuat laporan keuangan dan tidak } \\
\text { mempublikasikannya secara luasserta berturut- turut } \\
\text { periode tahun 2018 - 2020. }\end{array}$ & (35) \\
\hline 3. & $\begin{array}{l}\text { Selama periode penelitian, perusahaan tidak } \\
\text { membagikan dividen secara berturut-turut mulai tahun } \\
2018 \text { - 2020. }\end{array}$ & (90) \\
\hline
\end{tabular}




\begin{tabular}{|c|l|c|}
\hline 4. & $\begin{array}{l}\text { Perusahaan yang mengalami rugi selama tahun 2018 - } \\
2020\end{array}$ & (2) \\
\hline 5. & $\begin{array}{l}\text { Perusahaan yang tidak mengalami kenaikan penjualan } \\
\text { selama tahun 2018 - 2020 }\end{array}$ & (9) \\
\hline & Jumlah Perusahaan yang diteliti & 16 \\
\hline & Jumlah Sampel penelitian16 x 3 & 48 \\
\hline
\end{tabular}

Mengingat alat analisa yang digunakan adalah analisis regresi linier berganda dan data penelitian yang digunakan adalah data sekunder, maka untuk memenuhi syarat yang ditentukan dalam penggunaan model regresi linier berganda perlu dilakukan pengujian atas beberapa asumsi klasik yang digunakan yaitu: uji normalitas, multikolinearitas, autokorelasi dan heteroskedastisitas

\section{HASIL PENELITIAN DAN PEMBAHAS}

\section{Pengujian Asumsi Klasik}

a. Uji Normalitas

Uji normalitas bertujuan untuk mengetahui apakah dalam model regresi, variabel terikat dan variabel bebas memiliki distribusi normal atau tidak. Model regresi yang baik adalah memiliki distribusi data normal atau mendekati normal. Pengujian normalitas ini dapat dilakukan melalui analisis grafik dan analisis statistik.

1) Analisis Grafik

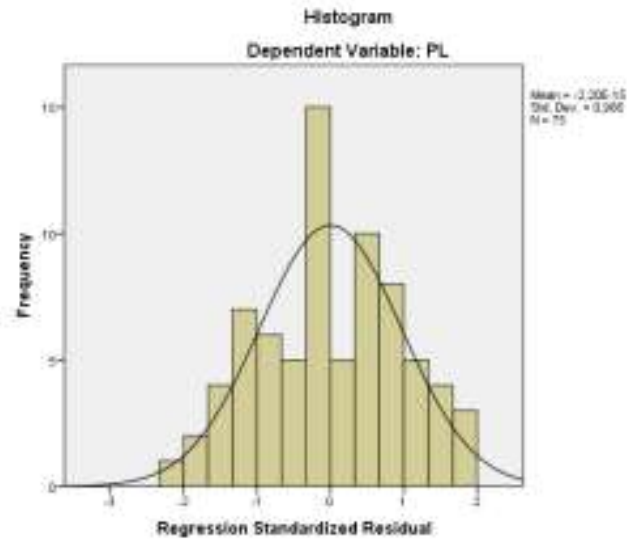

Gambar : Hasil Uji Normalitas Grafik Histogram

Sumber: output SPSS

Berdasarkan gambar diatas dapat dilihat bahwa data telah berdistribusi normal. Hal ini ditunjukkan oleh gambar tersebut yang sudah memenuhi dasar pengambilan keputusan, bahwa pada gambar grafik histogram kurva membentuk lonceng dan terbagi dua sama besar, selain itu titik puncak ada dititik 0 maka dapat dikatakan model ini telah memenuhi asumsi normalitas 


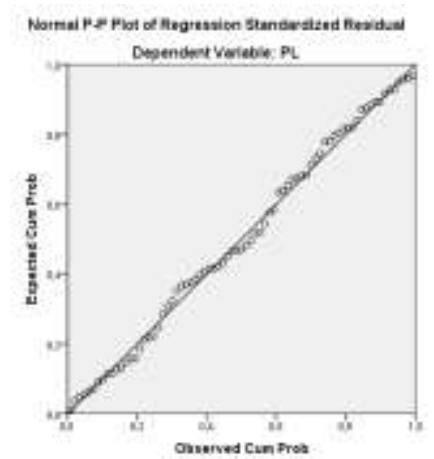

Gambar : Uji Normalitas Grafik Normal Probability KDot Sumber: output SPSS

Berdasarkan gambar diatas dapat dilihat bahwa data telah terdistribusi normal. Hal ini ditunjukkan oleh gambar tersebut yang sudah memenuhi dasar pengambilan keputusan, bahwa data menyebar disekitar garis diagonal dan mengikuti arah garis diagonal menunjukkan pola distribusi normal, maka model regresi memenuhi asumsi normalitas.

2) Analisis statistik

Untuk mendeteksi normalitas data dapat dilakukan pula melalui analisis statistik yang salah satunya dapat dilihat melalui KolmogorovSmirnov test (K-S). Berikut hasil uji analisis statistik Kolmogorov-Smirnov test (K-S) dengan menggunakan taraf signifikan sebesar 0,05 atau 5\%, ditunjukkan pada Tabel di bawah ini.

Tabel Hasil Uji Kolmogorov-Smirnov Test One-SamKDe Kolmogorov-Smirnov Test

\begin{tabular}{llr}
\hline & & $\begin{array}{c}\text { Unstandardized } \\
\text { Residual }\end{array}$ \\
\hline $\mathrm{N}$ & Mean & 48 \\
Normal Parameters ${ }^{\mathrm{a}, \mathrm{b}}$ & Std. Deviation &, 0000000 \\
& Absolute & 1,8463892 \\
& 0038 \\
Most Extreme Differences & Positive &, 069 \\
& Negative &,- 059 \\
Kolmogorov-Smirnov Z & &, 499 \\
Asymp. Sig. (2-tailed) & &, 771 \\
\hline a. Test distribution is Normal. & \\
b. Calculated from data. &
\end{tabular}

Sumber: output SPSS

Uji normalitas dengan menggunakan Kolmogorov-Smirnov (K-S) menunjukkan bahwa data residual yang diolah adalah berdistribusi normal, hal ini dapat dilihat pada tabel yang menunjukkan tingkat signifikansi sebesar 0,771 angka ini jauh lebih besar dari $\alpha=0,05$ sehingga hasil ini menunjukkan data berdistribusi normal.

b. Multikolinearitas

Untuk mendeteksi ada atau tidaknya multikoliniaritas dapat dilihat antara lain : 
a) Nilai $\mathrm{R}^{2}$ yang dihasilkan oleh suatu estimasi model regresi empiris sangat tinggi, tetapi secara individual variabel-variabel independen banyak yang tidak signifikan mempengaruhi variabel dependen.

b) Dari tolerance value atau nilai Variance Inflation Factor (VIF) dimana : Tolerance value $<0,10$ atau VIF $>10=$ terjadi multikolinieritas, dan Tolerance value $>0,10$ atau $\mathrm{VIF}<10=$ tidak terjadi multikolinieritas

Berikut hasil uji multikolinieritas dari analisis matrik korelasi antar variabel bebas dan perhitungan nilai Tolerance dan VIF, ditunjukkan pada tabeldi bawah ini.

Tabel Hasil Uji Multikolinearitas Coefficients $^{\mathrm{a}}$

\begin{tabular}{|c|c|c|c|}
\hline \multirow{2}{*}{\multicolumn{2}{|c|}{ Model }} & \multicolumn{2}{|c|}{ Collinearity Statistics } \\
\hline & & Tolerance & VIF \\
\hline \multirow{4}{*}{1} & (Constant) & & \\
\hline & $\mathrm{CF}$ & ,510 & 1,439 \\
\hline & NPM & ,982 & 1,099 \\
\hline & SIZE & 678 & 1,321 \\
\hline
\end{tabular}

a. Dependent Variable: KD

Sumber: output SPSS

Uji asumsi klasik yang kedua adalah uji multikolinearitas. Pada model regresi yang baik seharusnya antar variabel independen tidak terjadi korelasi. Berdasarkan tabel dapat dilihat bahwa variabel CF, NPM, dan Ukuran Perusahaan memiliki nilai Tolerance sebesar lebih besar dari 0,10 dan VIF yang lebih kecil dari 10 dengan demikian dalam model ini tidak ada masalah multikolinieritas.

c. Uji Autokorelasi

Tabel Hasil Uji Autokorelasi

Model Summary ${ }^{\text {b }}$

\begin{tabular}{llrrrr}
\hline Model & R & R Square & $\begin{array}{c}\text { Adjusted R } \\
\text { Square }\end{array}$ & $\begin{array}{c}\text { Std. Error of the } \\
\text { Estimate }\end{array}$ & Durbin-Watson \\
\hline 1 &, $719^{\mathrm{a}}$ &, 516 &, 502 & 1,34052 & 2,0121 \\
\hline
\end{tabular}

a. Predictors: (Constant), SIZE, NPM, CF,

b. Dependent Variable: KD

Sumber: output SPSS

Uji asumsi klasik yang ketiga adalah uji autokorelasi. Menurut (Ghozali, 2011) dengan melihat Durbin Watson dengan ketentuan du $<\mathrm{dw}<$ 4-du jika nilai dw terletak antara du dan 4 - du berarti bebas dari autokorelasi. Berdasarkan hasil perhitungan DW lebih dari du dan kurang dari 4-du sehingga model regresi tersebut sudah bebas dari masalah autokorelasi.

d. Uji Heterokedatisitas

Berikut adalah hasil uji heterokedastisitas dengan menggunakan grafik scatterplot ditunjukkan pada gambar di bawah ini: 


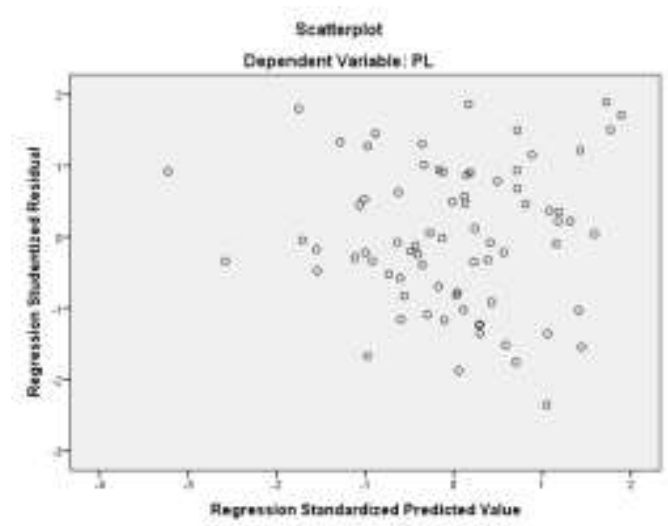

Gambar Grafik Scatterplot

Sumber: output SPSS

Uji asumsi klasik yang terakhir adalah uji heteroskedastisitas. Berdasarkan gambar yang ditunjukkan oleh grafik scatterplot terlihat bahwa titik-titik menyebar secara acak serta tersebar baik diatas maupun dibawah angka 0 pada sumbu Y.

\section{Analisis Regresi Linier Berganda}

Untuk mengetahui apakah ada pengaruh yang signifikan dari beberapa variabel independen terhadap variabel dependen maka digunakan model regresi linier berganda yang dirumuskan sebagai berikut:

$$
Y=\alpha+\beta_{1} X_{1}+\beta_{2} X_{2}+\beta_{3} X_{3}+e
$$

Keterangan:

$\mathrm{Y} \quad=$ Kebijakan Dividen

a $\quad=$ konstanta

$\mathrm{b}_{1,2,3}, \quad=$ koefisien regresi variabel

$\mathrm{X}_{1}=$ Cash Flow

$\mathrm{X}_{2}=$ Net Profit Margin

$\mathrm{X}_{3}=$ Ukuran perusahaan

$\mathrm{e} \quad=$ standart error berikut:

Perhitungan analisis regresi dapat dilihat pada tabel sebagai

Tabel Hasil Analisis Regresi Linier Berganda Coefficients $^{\mathrm{a}}$

\begin{tabular}{llccccc}
\hline Model & & \multicolumn{2}{c}{ Unstandardized Coefficients } & $\begin{array}{c}\text { Standardized } \\
\text { Coefficients }\end{array}$ & T & \multirow{2}{*}{ Sig. } \\
\cline { 3 - 6 } \multicolumn{1}{c}{} & \multicolumn{1}{c}{$\mathrm{B}$} & Std. Error & Beta & & \\
\hline & (Constant) & 4,987 & 3,401 & & 1,789 &, 089 \\
1 & CF &,- 321 &, 097 &,- 199 & $-1,349$ &, 110 \\
& NPM &, 187 &, 201 &, 311 & 2,221 &, 043 \\
& SIZE & $-2,881$ & 1,298 &,- 301 & $-2,728$ &, 011 \\
\hline
\end{tabular}

a. Dependent Variable: KD

Sumber: data sekunder yang diolah 


\section{Pengujian Hipotesis}

a. Pengujian Hipotesis Secara Parsial (Uji t)

Berikut ini merupakan hasil pengujian secara parsial menggunakan uji t yang nilainya akan dibandingkan dengan signifikansi 0,05 atau 5\%.

Tabel Hasil Uji t (Parsial) Coefficients $^{\mathrm{a}}$

\begin{tabular}{llccccc}
\hline Model & & \multicolumn{2}{c}{ Unstandardized Coefficients } & $\begin{array}{c}\text { Standardized } \\
\text { Coefficients }\end{array}$ & T & Sig. \\
\cline { 3 - 5 } & & B & Std. Error & Beta & & \\
\cline { 3 - 5 } & (Constant) & 4,987 & 3,401 & & 1,789 &, 089 \\
1 & CF &,- 321 &, 097 &,- 199 & $-1,349$ &, 110 \\
& NPM &, 187 &, 201 &, 311 & 2,221 &, 043 \\
& SIZE & $-2,881$ & 1,298 &,- 301 & $-2,728$ &, 011 \\
\hline
\end{tabular}

a. Dependent Variable: KD

Sumber: output SPSS

Pengujian secara parsial menggunakan uji t (pengujian signifikansi secara parsial) dimaksudkan untuk mengetahui seberapa jauh pengaruh $\mathrm{CF}$ $\left(\mathrm{X}_{1}\right)$, NPM $\left(\mathrm{X}_{2}\right)$ dan Size $\left(\mathrm{X}_{3}\right)$, secara individual terhadap Kebijakan Dividen (Y).

1) Pengujian Hipotesis 1

$\mathrm{H}_{0}: \mathrm{b}_{1}=0 \mathrm{CF}\left(\mathrm{X}_{1}\right)$ tidak berpengaruh secara parsial terhadap Kebijakan Dividen (Y).

$\mathrm{H}_{\mathrm{a}}: \mathrm{b}_{1} \neq 0 \mathrm{CF}\left(\mathrm{X}_{1}\right)$ berpengaruh secara parsial terhadap Kebijakan Dividen (Y).

Berdasarkan hasil perhitungan pada SPSS dalam tabel diperoleh nilai probabilitas sebesar 0,110 . Nilai signifikansi yang lebih besar dari 0,05 , yang berarti $\mathrm{H}_{0}$ diterima dan $\mathrm{H}_{\mathrm{a}}$ ditolak. Hal ini menunjukkan bahwa variabel $\mathrm{CF}$ tidak memiliki pengaruh yang signifikan terhadap Kebijakan Dividen.

2) Pengujian Hipotesis 2

$\mathrm{H}_{0}: \mathrm{b}_{3}=0 \mathrm{NPM}\left(\mathrm{X}_{2}\right)$ tidak berpengaruh secara parsial terhadap Kebijakan Dividen (Y).

$\mathrm{H}_{\mathrm{a}}: \mathrm{b}_{3} \neq 0 \mathrm{NPM}\left(\mathrm{X}_{2}\right)$ berpengaruh secara parsial terhadap Kebijakan Dividen (Y).

Berdasarkan hasil perhitungan pada SPSS dalam tabel 4.11 diperoleh nilai probabilitas sebesar 0,043. Nilai signifikansi lebih kecil dari 0,05, yang berarti $\mathrm{H}_{0}$ ditolak dan $\mathrm{H}_{\mathrm{a}}$ diterima. Hal ini menunjukkan bahwa variabel NPM memiliki pengaruh yang signifikan terhadap Kebijakan Dividen.

3) Pengujian Hipotesis 3

$\mathrm{H}_{0}: \mathrm{b}_{5}=0$ Size $\left(\mathrm{X}_{3}\right)$ tidak berpengaruh secara parsial terhadap Kebijakan Dividen (Y).

$\mathrm{H}_{\mathrm{a}}: \mathrm{b}_{5} \neq 0$ Size $\left(\mathrm{X}_{3}\right)$ berpengaruh secara parsial terhadap Kebijakan Dividen (Y).

Berdasarkan hasil perhitungan pada SPSS dalam tabel diperoleh nilai probabilitas sebesar 0,011 . Nilai signifikansi lebih besar dari 0,05, yang berarti $\mathrm{H}_{0}$ ditolak dan $\mathrm{H}_{\mathrm{a}}$ diterima. Hal ini menunjukkan 
bahwa variabel Size memiliki pengaruh yang signifikan terhadap Kebijakan Dividen.

b. Pengujian Hipotesis Secara Simultan (Uji F)

$\mathrm{H}_{0}: \mathrm{b}_{1}=\mathrm{b}_{2},=\mathrm{b}_{3},=0$ secara simultan tidak berpengaruh antara $\mathrm{CF}$, NPM, dan Ukuran Perusahaan terhadap Kebijakan Dividen.

Ha $: b_{1} \neq b_{2}, \neq b_{3} \neq 0$ secara simultan berpengaruh antara CF, NPM, dan Ukuran Perusahaan terhadap Kebijakan Dividen.

Pengujian Hipotesis Secara Parsial (Uji t)

Hasil dari pengujian statistik secara simultan dapat dilihat pada tabel berikut ini :

Tabel Hasil Uji F

ANOVA $^{\mathrm{a}}$

\begin{tabular}{rlrcccc}
\hline Model & & Sum of Squares & df & Mean Square & F & Sig. \\
\hline \multirow{2}{*}{1} & Regression & 21,871 & 3 & 4,819 & 3,192 &, $000^{\mathrm{b}}$ \\
& Residual & 89,798 & 68 & 1,721 & & \\
& Total & 129,102 & 72 & & & \\
\hline
\end{tabular}

a. Dependent Variable: KD

b. Predictors: (Constant), SIZE, NPM, CF, PER, DER

Sumber: output SPSS

Berdasarkan hasil perhitungan pada SPSS dalam tabel diperoleh nilai signifikan adalah 0,000 . Hal ini menunjukkan bahwa nilai signifikan variabel CF $\left(\mathrm{X}_{1}\right)$, NPM $\left(\mathrm{X}_{2}\right)$, dan Size $\left(\mathrm{X}_{3}\right)<0,05$ yang berarti $\mathrm{H}_{0}$ ditolak dan $\mathrm{H}_{\mathrm{a}}$ diterima. Hal ini menunjukkan bahwa secara simultan $\mathrm{CF}\left(\mathrm{X}_{1}\right)$, NPM $\left(\mathrm{X}_{2}\right)$, dan Size $\left(\mathrm{X}_{3}\right)$ berpengaruh signifikan terhadap Kebijakan Dividen. berikut ini

Untuk lebih jelasnya, rekapitulasi hasil analisis disajikan dalam tabel Tabel Rekapitulasi Hasil Analisis

\begin{tabular}{|l|l|c|l|}
\hline \multicolumn{1}{|c|}{ Jenis Uji } & Variabel & Nilai Sign. & \multicolumn{1}{|c|}{ Kriteria } \\
\hline Uji t (parsial) & CF & $0,110>0.05$ & $\begin{array}{l}\text { CF tidak berpengaruh } \\
\text { signifikan terhadap } \\
\text { Kebijakan Dividen. }\end{array}$ \\
\hline Uji t (parsial) & NPM & $0,043<0.05$ & $\begin{array}{l}\text { NPM berpengaruh } \\
\text { terhadap } \\
\text { Kebifikan Danan Dividen. }\end{array}$ \\
\hline Uji t (parsial) & Size & $0,011<0.05$ & $\begin{array}{l}\text { Size berpengaruh } \\
\text { signifikan terhadap } \\
\text { Kebijakan Dividen. }\end{array}$ \\
\hline $\begin{array}{l}\text { Uji } \\
\text { (simultan) }\end{array}$ & $\begin{array}{l}\text { FF, } \\
\text { NPM, } \\
\text { dan Size }\end{array}$ & $0,000<0.05$ & $\begin{array}{l}\text { CF, NPM, dan Size } \\
\text { berpengaruh signifikan } \\
\text { secara simultan terhadap } \\
\text { Kebijakan Dividen. }\end{array}$ \\
\hline
\end{tabular}

Sumber: data sekunder, 


\section{Pembahasan}

\section{a. Pengaruh Cash Flow terhadap Kebijakan Dividen}

Hasil dari pengujian hipotesis yang telah dilakukan, menunjukkan bahwa secara parsial Cash Flow tidak berpengaruh signifikan terhadap Kebijakan Dividen. Berdasarkan pengujian diperoleh nilai signifikan uji t sebesar 0,110. Nilai tersebut lebih besar dari $\alpha=0.05$. Cash Flow tidak berpengaruh terhadap kebijakan dividen karena ada kecenderungan Cash Flow tidak secarara langsung mecerminakan kondisi keuangan keuangan sehingga kurang bisa digunakan dalam pengambilan keputusan terkait kebijakan dividen.

Hasil penelitian ini sesuai dengan hasil penelitian terdahulu yang dilakukan oleh (Astuti, 2020) dan penelitian dari (Daulay \& Setyowati, 2021), Penelitian dari (Ulfa et al., 2020) dan (Lariwu et al., 2020) menyebutkan bahwa secara parsial (individual) variabel CF tidak berpengaruh terhadap Kebijakan Dividen.

\section{b. Pengaruh Net Profit margin terhadap Kebijakan Dividen}

Hasil dari pengujian hipotesis yang telah dilakukan, menunjukkan bahwa secara parsial Net Profit margin berpengaruh signifikan terhadap Kebijakan Dividen. Berdasarkan pengujian diperoleh nilai signifikan uji t sebesar 0,043. Nilai tersebut lebih kecil dari $\alpha=0.05$. Menurut (Harjito, 2010) Net Profit Margin adalah keuntungan penjual setelah menghitung seluruh biaya dan pajak penghasilan.

Hasil penelitian ini sesuai dengan penelitian dari (Jurnal \& Mea, 2021), penelitian dari (Lubis et al., 2020) dan penelitian dari (Nur \& Amaliyah, 2019) juga menemukan bahwa Net Profit margin berpengaruh signifikan terhadap Kebijakan Dividen.

\section{c. Pengaruh Ukuran Perusahaan terhadap Kebijakan Dividen}

Hasil dari pengujian hipotesis yang telah dilakukan, menunjukkan bahwa secara parsial Ukuran Perusahaan berpengaruh signifikan terhadap Kebijakan Dividen. Berdasarkan diperoleh nilai signifikan uji t sebesar 0,011. Nilai tersebut lebih kecil dari $\alpha=0.05$, maka hipotesis $\mathrm{H}_{\mathrm{a}}$ diterima yang berarti bahwa secara parsial Ukuran Perusahaan berpengaruh signifikan terhadap Kebijakan Dividen. Ukuran perusahaan (Size) ini mempunyai pengaruh terhadap Kebijakan Dividen karean semakin besar perusahaan secara langsung akan membagikan dividen semakin besar juga seiring dengan pendapatan yang diperoleh.

Hasil penelitian ini sesuai dengan penelitian dari (Dividen \& Kartika, 2020), (Septirini et al., 2021), (Karjono, 2019) dan Penelitian dari Kadim dan (Dewi \& Muliati, 2020) juga menemukan bahwa Ukuran perusahaan berpengaruh signifikan terhadap Kebijakan Dividen. Namun hasil penelitian ini tidak sesuai dengan penelitian dari (Cristna et al., 2021), (Mayanti et al., 2021) dan penelitian dari (Firza, 2021) yang mendapatkan hasil berbeda bahwa ukuran perusahaan tidak berpengaruh terhadap Kebijakan Dividen 


\section{d. Pengaruh Cash Flow, Net Profit Margin ,dan Ukuran Perusahaan terhadap Kebijakan Dividen}

Hasil dari pengujian hipotesis yang telah dilakukan, menunjukkan bahwa secara simultan Cash Flow, Net Profit Margin, dan Ukuran Perusahaan berpengaruh signifikan terhadap Kebijakan Dividen. Berdasarkan tabel diperoleh nilai signifikan uji $\mathrm{F}$ sebesar 0,000 yang artinya lebih kecil dari tingkat signifikansi yaitu 0,05 atau $5 \%$. Maka $\mathrm{H}_{0}$ ditolak dan $\mathrm{H}_{\mathrm{a}}$ diterima, sehingga dapat disimpulkan bahwa secara simultan Cash Flow, Net Profit Margin, dan Ukuran Perusahaan berpengaruh signifikan terhadap Kebijakan Dividen.

\section{KESIMPULAN}

Penelitian ini bertujuan untuk meneliti pengaruh Cash Flow, profitabilitas yang diukur dengan Net Profit Margin, dan Ukuran Perusahaan terhadap Kebijakan Dividen pada perusahaan manufaktur yang terdaftar di Bursa Efek Indonesia periode 2018-2020. Dari hasil pengujian dapat diambil kesimpulan sebagai berikut:

1. Berdasarkan hasil pengujian secara parsial menunjukkan bahwa Cash Flow tidak berpengaruh signifikan terhadap Kebijakan Dividen.

2.Berdasarkan hasil pengujian secara parsial menunjukkan bahwa profitabilitas yang diukur dengan Net Profit Margin berpengaruh signifikan terhadap Kebijakan Dividen.

3.Berdasarkan hasil pengujian secara parsial menunjukkan bahwa Ukuran Perusahaan berpengaruh signifikan terhadap Kebijakan Dividen.

4.Berdasarkan hasil pengujian secara simultan menunjukkan bahwa likuiditas, profitabilitas dan Ukuran Perusahaan berpengaruh signifikan terhadap Kebijakan Dividen.

\section{DAFTAR PUSTAKA}

Anggraeni, P. R., \& Ridwan, A. (2020). Pengaruh Kebijakan Dividen, Kebijakan Hutang, Profitabilitas, Dan Likuiditas Terhadap Harga Saham. Jurnal Akuntansi Aktual, 7 (1(, 31-44. https://doi.org/10.17977/um004v7i12020p31

Aryani, I. Z., \& Fitria. (2020). Pengaruh Leverage, Likuiditas, Profitabilitas, dan Ukuran Perusahaan Terhadap Kebijakan Dividen. Jurnal Ilmu dan Riset Akuntansi. e-ISSN:2460-0585.

Astuti, N. (2020). Pengaruh Earning Per Share, Net Profit Margin, Free Cash Flow dan Likuiditas Terhadap Kebijakan Dividen pada Perusahaan yang Terdaftar di Jakarta Islamic Index (JII) Periode 2016-2018. Jurnal Pasar Modal Dan Bisnis, 2(2), 217-226. https://doi.org/10.37194/jpmb.v2i2.53

Cristna, Jackline, Gotami, D., Patricia, \& Katharina, N. (2021). Pengaruh Ukuran Perusahaan, Profitabilitas, Likuiditas. Pertumbuhan Perusahaan, Dan Leverage Terhadap Kebijakan Dividen Pada Industri Makanan Dan Minuman Yang Terdaftar Di Bursa Efek Indonesia Tahun 2017-2019. SOSEK: Jurnal Sosial Dan Ekonomi, 2(2), 81-88. http://www.jurnal.bundamediagrup.co.id/index.php/sosek/article/view/102 
Daulay, Y., \& Setyowati, T. (2021). P engaruh free cash flow dan investment opportunity set terhadap kebijakan dividen pada industri plastik dan kemasan di indonesia yang terdaftar di bursa efek indonesia tahun 20132017 The effect of free cash flow and investment opportunity set on dividen. $13(2), 305-314$.

Dewi, N. K. A., \& Muliati, N. K. (2020). PENGARUH PROFITABILITAS, UKURAN PERUSAHAAN DAN LIKUIDITAS TERHADAP KEBIJAKAN DIVIDEN (Studi Empiris Pada Perusahaan Manufaktur Di Bursa Efek Indonesia Tahun 2015-2019). Hita Akuntansi Dan Keuangan Universitas Hindu Indonesia, April, 699-730.

Dividen, M. K., \& Kartika, A. (2020). Fokus ekonomi. 4, 356-371.

Firza, S. U. (2021). Peran cash holding dalam memediasi kinerja keuangan dan ukuran perusahaan terhadap kebijakan dividen. Jurnal Wira Ekonomi Mikroski, 11(April), 51-64.

Gautama, P. B., \& Haryati, Y (2014). Pengaruh Struktur Kepemilikan Dan Kebijakan Hutang Terhadap Kebijakan Dividen Pada Subsektor Konstruksi Dan Bangunan Yang Tercatat Di BEI. IMAGE, III(2), November.

Ghozali, I. (2011). Aplikasi Multivariate Dengan Program IMB SPSS 21 (Semarang). Universitas Diponegoro.

Harjito, M. dan A. (2010). Manajemen Keuangan. Ekonisia.

Jurnal, J., \& Mea, I. (2021). FAKTOR-FAKTOR YANG MEMPENGARUHI KEBIJAKAN DIVIDEN PADA PERUSAHAAN TRADE , SERVICE AND JIMEA | Jurnal Ilmiah MEA ( Manajemen , Ekonomi , dan Akuntansi ). 5(2), 579-596.

Karjono, A. (2019). Pengaruh Cash Ratio, Net Profit Margin, Debt to Equity Ratio, dan Firm Size terhadap Kebijkan Dividen. Jurnal Manajemen Bisnis, 22(3), 270-288.

Kasmir. (2014). Analisis Laporan Keuangan (Integrated). Grasindo

Kresna, S, H., \& Ardini, L. Pengaruh Free Cash Flow, Profitabilitas, Kebijakan Hutang Terhadap Kebijakan Dividen. Jurnal Ilmu dan Riset Akuntansi.

Lariwu, S. V., Saerang, I. S., \& Maramis, J. B. (2020). Pengaruh Dispersion Of Ownership , Institusional Ownership, dan Free Cash Flow Terhadap Kebijakan Dividen Pada Perusahaan Manufaktur Di Bursa Efek Indonesia ( Periode 2014-2018 ) The Effect Of Dispersion Of Ownership, Institutional Ownership , and Free. Jurnal EMBA: Jurnal Riset Ekonomi, Manajemen, Bisnis Dan Akuntansi, 8(4), 1142-1151.

Lubis, M. S., Nasution, Y. A., \& Suryenti, E. (2020). Pengaruh Struktur Modal, Net Profit Margin (NPM) Dan Ukuran Perusahaan Terhadap Kebijakan Dividen Pada Perusahaan Sub Terdaftar Di Bursa Efek Indonesia Periode 2011-2015. Jurnal Ekonomi Bisnis Manajemen Prima, II(1).

Mayanti, N. M. D., Endiana, I. D. M., Pramesti, I. G. A. A., \& Rahmadani, D. A. (2021). Pengaruh Kinerja Keuangan, Ukuran Perusahaan, dan Kebijakan Hutang Terhadap Kebijakan Dividen Pada Perusahaan Sub Sektor Food and Beverage yang Terdaftar di Bursa Efek Indonesia (BEI) Periode 2016-2019. KARMA (Karya Riset Mahasiswa Akuntansi), 1(1), 297-308.

Mui, Y. T. \& Mustapha, M. (2016). Determinants Of Dividend Payout Ratio:Evidence Form Malaysian Public Listed Firms. J. Appl. Environ. Biol. Sci., 6 (1s): 48-54 
Munfarid, C, S. (2021). Pengaruh Free Cash Flow, Profitabilitas, Kebijakan Hutang Dan Likuiditas Terhadap Kebijakan Dividen (Studi Empiris Pada Perusahaan Manufaktur Yang Terdaftar Di Bursa Efek Indonesia Tahun 2016-2020).

Nur, Y., \& Amaliyah, F. (2019). PENGARUH STRUKTUR MODAL , PROFITABILITAS , DAN KEBIJAKAN ( Studi Pada Perusahaan Sektor Pertambangan Batubara yang Terdaftar di BEI Pada Tahun 2015-2019 ) Sekolah Tinggi Ilmu Ekonomi Indonesia ( STIESIA ) Surabaya.

Pradnyavita, K. I., \& Suryanawa, I. K. (2020). Pengaruh Profitabilitas, Ukuran Perusahaan, dan Arus Kas Bebas, Terhadap Kebijakan Dividen Kadek. EJurnal Akuntansi, 30(1), 238-250.

Puspitaningtyas, Z., Prakoso, A., \& Masruroh A. (2019). pengaruh profitabilitas terhadap kebijakan dividen dengan likuiditas sebagai pemoderasi.

Septirini, V., Mardani, R. M., \& Saraswati, E. (2021). Pengaruh Leverage, Likuiditas, Profitabilitas, Ukuran Perusahaan, Dan Tingkat Pertumbuhan Perusahaan Terhadap Kebijakan Dividen (Studi Empiris Pada Perbankan Yang Terdaftar Di Bursa Efek Indonesia Tahun 2017-2019). Jurnal Ilmiah Riset Manajemen, 10(5), 92-107.

Subramanyam, K. ., \& Wild, J. J. (2017). Analisis Laporan Keuangan (Buku 2). Salemba Empat.

Sugiyono. (2013). Penelitian Kuantitatif, Kualitatif Dan R\&D. Alfabeta.

Ulfa, M., Wijaya, A. L., \& Ubaidillah, M. (2020). Pengaruh Profitabilitas, Likuiditas, Kebijakan Hutang, Free Cash Flow Terhadap Kebijakan Dividen Dengan Ukuran Perusahaan Sebagai Moderasi (Studi Kasus Pada Sektor Perusahaan Industri Barang Konsumsi yang Terdaftar di BEI 2015-2018). Simba.

Vidia, P. \& Darmayanti, Ayu, NP. (2016). Pengaruh Penyebaran Kepemilikan, Jaminan Aset, Posisi Kas, Dan Return On Assets Terhadap Kebijakan Dividen. E-Jurnal Manajemen Unud, 5(10), 6116-6415.

Windyasari, Raiza H. \& Widyawati, D. (2017). Pengaruh Return On Asset, Debt To Equity Ratio, dan Collateral Asset Terhadap Kebijakan Dividen. Jurnal Ilmu dan Riset Akuntansi, 6(11), November 2017 